\title{
Relationship of Wheat Yield with Agroclimatic Indices under Varying Thermal Regimes, Nitrogen Levels and Stress Management Strategies
}

\author{
Sukhjeet Kaur ${ }^{*}$, Som Pal Singh and P. K. Kingra
}

School of Climate Change and Agricultural Meteorology, Punjab Agriculture University, Ludhiana, Punjab (141 004), India

\section{Article History}

Manuscript No. AR1595

Received in $9^{\text {th }}$ May, 2016

Received in revised form $20^{\text {th }}$ June, 2016

Accepted in final form $4^{\text {th }}$ August, 2016

\section{Correspondence to}

"E-mail: sukhjeetkaur88@gmail.com

\section{Keywords}

Wheat, agroclimate, heat use efficiency, grain yield, corelation

\begin{abstract}
The field experiments were carried out during rabi seasons of 2013-14 and 2014-15 at Research Farm, School of Climate Change and Agricultural Meteorology, PAU, Ludhiana to study the effect of different temperature regimes, nitrogen levels and post anthesis strategies on phenology growth, development and grain yield of wheat. The experiment was laid out in Split- Split plot design having three temperature regimes $\left(\mathrm{D}_{1}=\right.$ October $30, \mathrm{D}_{2}=$ November 15 and $\mathrm{D}_{3}=$ November 30$)$ in main plot, three nitrogen levels $\left(\mathrm{N}_{1}=\mathrm{RDF}\right.$ (Recommended dose of $\left.\mathrm{N}\right), \mathrm{N}_{2}=125 \%$ RDF $(25 \%$ more than recommended $\mathrm{N}), \mathrm{N}_{3}=150 \% \mathrm{RDF}(50 \%$ more than recommended $\mathrm{N})$ in sub plot and four heat stress management post-anthesis strategies $\left(\mathrm{P}_{0}=\right.$ Control, $\mathrm{P}_{1}=$ Water sprayed, $\mathrm{P}_{2}=$ Foliar spray of $\mathrm{ZnSO}_{4} \cdot 7 \mathrm{H}_{2} 0(0.5 \%), \mathrm{P}_{3}=$ Thiourea $(10 \mathrm{mM})$ at anthesis and 20 days after anthesis in sub-sub plot during both years. The agrometeorological indices such as accumulated growing Degree Days (AGDD), heliothermal units (HTU), photo thermal units (PTU) and heat use efficiency (HUE) were calculated and their relation with grain yield was also observed. The results showed that the crop sown on October 30 with $150 \%$ RDF when spray at or after anthesis at regular intervals with any of stress alleviating chemicals such as $\mathrm{ZnSO}_{4} \cdot 7 \mathrm{H}_{2} \mathrm{O}(0.5 \%)$, Thiourea $(10$ $\mathrm{mM}$ ) or water accumulated more number of growing degree days, photo thermal units and had higher heat use efficiency than other treatments because crop exhibited best growth and development as the favorable environmental conditions concided with higher heat unit requirement of different phenophases and gave higher grain yield
\end{abstract}

\section{Introduction}

Wheat (Triticum aestivum L. emend. Feori \& Paul) is an important cereal crop of Indo-Gangetic plains of India in general and Punjab in particular. Wheat is a photo-insensitive and thermo-sensitive long day plant. Wheat requires cool climate during the early part of its growth. The research concerning the relationship between weather parameters and wheat yields is growing rapidly, exploit the role of temperature to determine yields (Tacka et al., 2015). Temperature is among main environmental factors affecting the growth and development of wheat. It influences the crop phenology and yield of crop (Bishnoi et al., 1995). Both the start and end of wheat crop season are limited by the onset and end of favorable temperature regimes. Phenological development from sowing to maturity is related to accumulation of heat or temperature units above threshold or base temperature (below which no growth occurs). A quantified value of heat or temperature units is required to reach a particular phenophase. During growth and development of a cereal crop several growth stages are distinguishable in which important physiological processes occur (Sikder, 2008). During past few years, wheat often got delayed till December or early January causing substantial loss in grain yield. Drastic reduction in yield of wheat has been recorded with the delay of sowing beyond optimum time. Delay in wheat sowing 20 and 40 days from the normal sowing date $\left(15^{\text {th }}\right.$ November) reduced grain yield by $23 \mathrm{~kg}$ $\mathrm{ha}^{-1}$ day $^{-1}$ and $30 \mathrm{~kg} \mathrm{ha}^{-1}$ day $^{-1}$, respectively (Kaur and Pannu, 2008). The crop sown on $5^{\text {th }}$ November took maximum calendar days, growing degree days, photo thermal unit, helio-thermal unit to attend different phenological stages till maturity which reduced significantly with subsequent delay in sowing time (Amrawat et al., 2013). The optimum sowing time and selection of improved cultivars play a remarkable role in exploiting the yield potential of the crop under particular agro climatic condition. The accumulated temperature is considered as the principal factor affecting year-to-year variation in phenology. In general, increasing temperatures accelerate phenological 
development by reducing growth period. GDD also changes with growing stage and permits to estimate the exact time of occurring growth stage in particular location and ultimately effect the grain yield (Sourour et al., 2016).

Air temperature based agromet indices viz., growing degree days (GDD), photothermal units (PTU), heliothermal units (HTU), phenothermal index (PTI) have been used to describe changes in phenological behaviour and growth parameters. The wheat crop sown on $20^{\text {th }}$ November consumed more photo and helio-thermal units as compared to $20^{\text {th }}$ December sown crop (Khicher and Niwas, 2007). Therefore late sowing shortened the development phases of wheat and adversely affected the grain development and thus the grain yield (Suleiman et al., 2014). Hence, it becomes imperative to have knowledge of the exact duration of phenological stages in a particular cropgrowing environment. Therefore, an experiment was conducted to determine the phenology and heat unit requirement of wheat varieties under different temperature regimes, nitrogen levels and post anthesis strategy.

\section{Materials and Methods}

A factorial experiment was laid out during Rabi season 2013-14 and 2014-15 in Split-Split plot design at the Research farm of School of Climate Change and Agricultural Meteorology, Punjab Agricultural University, Ludhiana with three temperature regimes $\left(D_{1}=\right.$ October $30, D_{2}=$ November 15 and $\mathrm{D}_{3}=$ November 30 ) in main plot, three nitrogen levels $\left(\mathrm{N}_{1}=\mathrm{RDF}\right.$ (Recommended dose of $\left.\mathrm{N}\right), \mathrm{N}_{2}=125 \%$ of $\mathrm{RDF}(25 \%$ more than recommended $\mathrm{N}$ ), $\mathrm{N}_{3}=150 \%$ of $\mathrm{RDF}(50 \%$ more than recommended $\mathrm{N}$ ) in sub plot and four heat stress management post-anthesis strategies $\left(\mathrm{P}_{0}=\right.$ Control, $\mathrm{P}_{1}=$ Water sprayed, $\mathrm{P}_{2}=$ Foliar spray of $\mathrm{ZnSO}_{4} .7 \mathrm{H}_{2} 0(0.5 \%), \mathrm{P}_{3}=$ Thiourea $(10 \mathrm{mM})$ at anthesis and 20 days after anthesis in sub-sub plot during both years. The accumulated growing degree days (AGDD), heliothermal units (HTU), photo thermal units (PTU) and heat use efficiency (HUE) were calculated. The phenological stages of crop were recorded by visual observations.

\subsection{Growing degree days (GDD)}

GDD were calculated by simple arithmetic accumulation of daily mean temperature above the base temperature value of $5{ }^{\circ} \mathrm{C}$ considered for the wheat crop. The different indices for each stage were calculated as suggested by (Nuttonson, 1955)

Growing degree days $\left({ }^{\circ} \mathrm{C}\right.$ day $\left.\mathrm{hr}\right)=\frac{\left(\mathrm{T}_{\max }+\mathrm{T}_{\min }\right)}{2}-\mathrm{T}_{\mathrm{b}}$ Where,

$\mathrm{T}_{\max }=$ Daily maximum temperature $\left({ }^{\circ} \mathrm{C}\right)$

$\mathrm{T}_{\text {min }}=$ Daily minimum temperature $\left({ }^{\circ} \mathrm{C}\right)$

$\mathrm{T}_{\mathrm{b}}=$ Base temperature $\left(5^{\circ} \mathrm{C}\right)$

\subsection{Heliothermal units (HTU)}

The HTU for a day represent the product of GDD and the bright sunshine hours for that day. The accumulated HTU for a particular phenophase was determined by using the following

formula:
Accumulated HTU $\left({ }^{\circ} \mathrm{C}\right.$ day $\left.\mathrm{hr}\right)=\sum_{i=1}^{n} \mathrm{GDD} \times$ Bright sunshine
hours hours

\subsection{Photothermal units (PTU)}

The PTU for a day represent the product of GDD and the day length for that day. The accumulated PTU for a particular phenophase was determined by using the following formula: Accumulated PTU $\left({ }^{\circ} \mathrm{C}\right.$ day $\left.\mathrm{hr}\right)=\sum_{i=1}^{n} \mathrm{GDD} \times$ Day length

\subsection{Heat use efficiency (HUE)}

The heat use efficiency was calculated using the following formula:

Heat Use Efficiency $\left(\mathrm{kg} \mathrm{ha}^{-1}{ }^{\circ} \mathrm{C} \mathrm{day}^{-1}\right)=\quad \begin{gathered}\begin{array}{c}\text { Grain or biological } \\ \text { yield }\left(\mathrm{kg} \mathrm{ha}^{-1}\right)\end{array} \\ \operatorname{AGDD}\left({ }^{\circ} \mathrm{C} \text { day }\right)\end{gathered}$ Where, AGDD $=$ Accumulated growing degree days $\left({ }^{\circ} \mathrm{C}\right.$ day $)$

\section{Results and Discussion}

\subsection{Weather variability during the crop growing seasons}

Meteorological conditions play a pivotal role in influencing the phenological development, growth characteristics and final yield and yield attributes of a crop. The mean monthly maximum and minimum temperature was recorded to be $24.6{ }^{\circ} \mathrm{C}$ and $11.7^{\circ} \mathrm{C}$ during crop growing season of 2013-14 and $24.5{ }^{\circ} \mathrm{C}$ and $12.4{ }^{\circ} \mathrm{C}$ during crop growing season of 2014-15. The mean monthly morning and evening relative humidity was recorded to be $90.4 \%$ and $50.9 \%$ during crop growing season of $2013-14$ and $90.1 \%$ and $56.5 \%$ during crop growing season of 2014-15. The mean sunshine hours was recorded to be $6.9 \mathrm{hr}$ during crop season 2013-14 and $6.0 \mathrm{hr}$ during crop growing season of 2014-15. The total amount of rainfall received was $212.4 \mathrm{~mm}$ during the crop season 201314 and $232.3 \mathrm{~mm}$ during the crop growing season of 2014-15 ( Figurer 1).

\subsection{Growing degree days (GDD)}

The heat unit or GDD was proposed to explain the relationship between growth duration and temperature. It required for different phenophases varied with date of sowing. The accumulated growing degree days (AGDD) taken from CRI to maturity are given for different temperature regime and nitrogen level and post anthesis strategy (Table 1). Among temperature regime, AGDD requirement for October 30 sown crop for maturity was 1616.0 , for November 15 , it was 
1563.4 and 1506.9 for November 30 sown crop for rabi season 2013-14 and for rabi season 2014-15, AGDD requirement for October 30, November 15 and November 30 sown crop for maturity were $1713.3,1705.3$ and 1651.1 respectively as shown in Table 1. The AGDD was decreased with the successive delay in sowing. The early sown crop had accumulated maximum AGDD at all phenological stages as compared to the rest. This

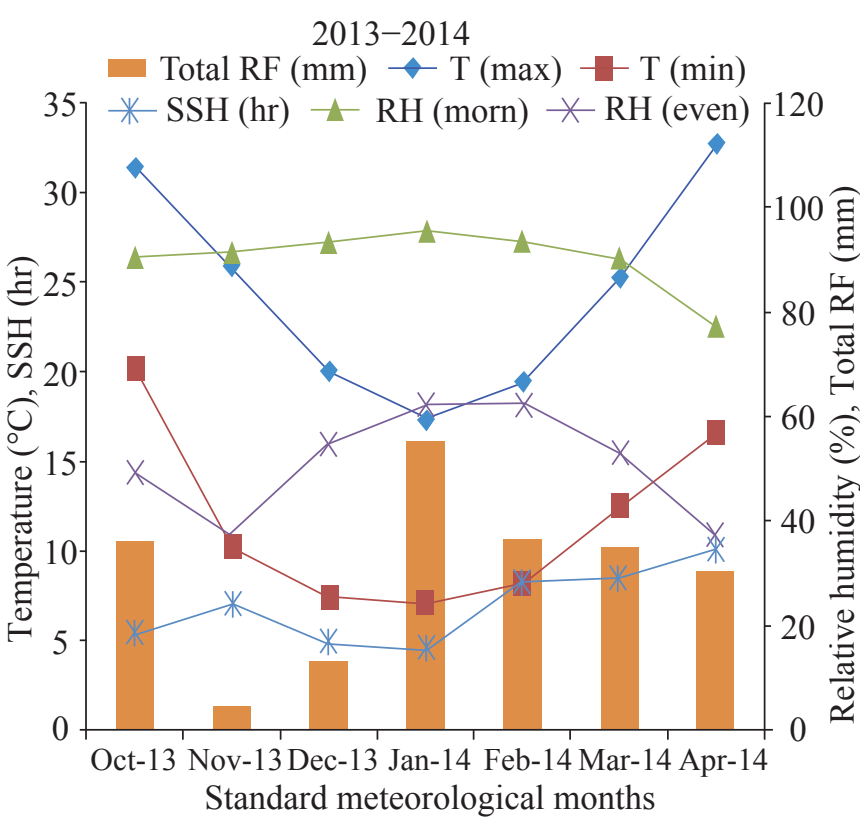

describes clearly the effect of temperature on phenological stage. Every crop needs a specific amount of GDD to enter its reproductive phase from vegetative phase. Early sowing resulted in absorbing sufficient GDD in relatively more time. While late sown crop experienced higher temperature during later stage in less time. The shorter phenophasic duration and lesser consumption of thermal units under late sown crop was

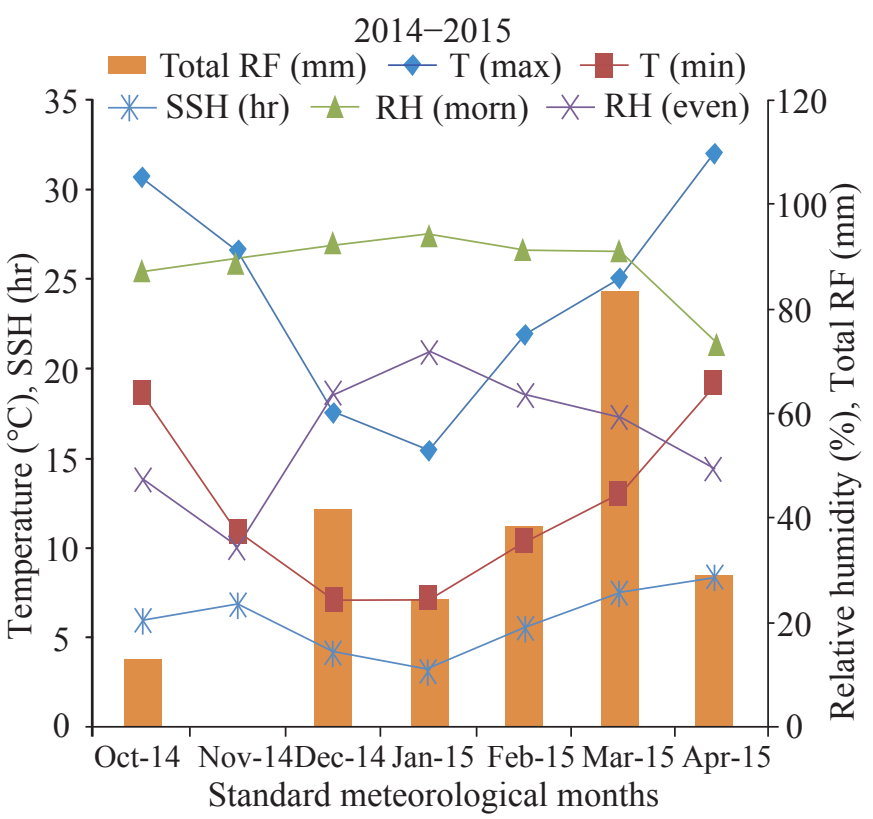

Figure 1: Mean monthly meteorological data during rabi 2013-14 and 2014-15

Table 1: Variation in accumulated growing degree days, heliothermal units and photothermal units for maturity under different temperature regime, nitrogen level and post anthesis strategy during rabi season 2013-14 and 2014-15

\begin{tabular}{|c|c|c|c|c|c|c|c|c|}
\hline \multirow[t]{2}{*}{ Treatment } & \multicolumn{2}{|c|}{$\begin{array}{c}\text { AGDD } \\
\left({ }^{\circ} \mathrm{C} \text { day }\right)\end{array}$} & \multicolumn{2}{|c|}{$\begin{array}{c}\text { AHTU } \\
\left({ }^{\circ} \mathrm{C} \text { day hrs }\right) \\
\end{array}$} & \multicolumn{2}{|c|}{$\begin{array}{c}\text { APTU } \\
\left({ }^{\circ} \mathrm{C} \text { day hrs }\right)\end{array}$} & \multicolumn{2}{|c|}{$\begin{array}{c}\text { Grain yield } \\
\left(\mathrm{q} \mathrm{ha}^{-1}\right)\end{array}$} \\
\hline & 2013-14 & 2014-15 & 2013-14 & 2014-15 & 2013-14 & $2014-15$ & 2013-14 & 2014-15 \\
\hline \multicolumn{9}{|l|}{ Temperature regimes } \\
\hline October 30 & 1616.0 & 1713.3 & 10310.8 & 10630.4 & 17773.5 & 19919.2 & 47.33 & 50.12 \\
\hline November 15 & 1563.4 & 1705.3 & 10892.6 & 10581.7 & 17518.2 & 18907.0 & 43.77 & 45.55 \\
\hline November 30 & 1506.9 & 1651.1 & 10486.7 & 11488.8 & 17257.8 & 18426.0 & 39.61 & 42.39 \\
\hline $\mathrm{CD}(p=0.05)$ & 25.8 & NS & 261.9 & 309.2 & 324.7 & 872.4 & 4.06 & 4.12 \\
\hline \multicolumn{9}{|l|}{ Nitrogen levels } \\
\hline $\mathrm{RDF}$ & 1527.5 & 1635.5 & 10216.9 & 10494.6 & 17071.4 & 18322.4 & 41.40 & 43.62 \\
\hline $125 \% \mathrm{RDF}$ & 1556.4 & 1703.1 & 10498.8 & 10952.4 & 17444.3 & 19270.2 & 43.58 & 46.81 \\
\hline $150 \% \mathrm{RDF}$ & 1602.5 & 1731.2 & 10974.4 & 11253.9 & 18033.8 & 19659.5 & 45.73 & 47.63 \\
\hline $\mathrm{CD}(p=0.05)$ & 43.0 & 63.9 & 409.4 & 817.5 & 551.3 & 403.8 & 2.11 & 2.69 \\
\hline \multicolumn{9}{|l|}{ Post anthesis strategies } \\
\hline Control & 1541.4 & 1653.2 & 10325.6 & 10523.5 & 17256.2 & 18589.6 & 42.12 & 45.31 \\
\hline Water sprayed & 1566.5 & 1695.1 & 10591.1 & 11040.7 & 17573.2 & 19312.1 & 42.25 & 45.44 \\
\hline $\mathrm{ZnSO}_{4} \cdot 7 \mathrm{H}_{2} \mathrm{O}(0.5 \%)$ & 1570.3 & 1726.4 & 10698.6 & 11150.8 & 17618.3 & 19276.4 & 44.13 & 47.46 \\
\hline Thiourea (10 mM) & 1570.3 & 1684.8 & 10638.2 & 10886.1 & 17618.4 & 19158.1 & 43.78 & 46.77 \\
\hline $\mathrm{CD}(p=0.05)$ & NS & NS & NS & NS & NS & NS & NS & NS \\
\hline
\end{tabular}


because of the fact that later stages of growth coincide with the abrupt rise in air temperature and thereby causing the shortening of later growth stages resulting in early maturity of crop. That is why, the thermal units consumed by the crop reduced progressively in case of delay in sowing. Sandhu et al. (1999); Paul and Sarker (2000); Pandey et al. (2010) also reported that the requirement of heat units decreased for different phenological stages with delay in sowing.

Among the nitrogen level, AGDD requirement for RDF from sowing to maturity was 1527.5 , for $125 \% \mathrm{RDF}$, it was 1556.4 and 1602.5 for $150 \%$ RDF for rabi season $2013-14$ and for rabi season 2014-15, AGDD requirement for RDF, $125 \%$ RDF and $150 \%$ RDF from sowing to maturity were 1635.5 , 1703.1 and 1731.2 respectively as shown in Table 1 . The crop took more number of days to complete one stage to another in $150 \% \mathrm{RDF}$ treatment because by applying more fertilizers, vegetative phase of crop got enhanced.

At anthesis or after that crop experienced high temperature stress during this stage which will result in shriveling of grains and reduction in yield of crop. To avoid this heat stress during grain filling by spraying the crop at anthesis and after that at regular intervals with water or any stress alleviating chemicals help the crop to combat with this stress period. Among postanthesis strategies, The AGDD requirement for $\mathrm{ZnSO}_{4} \cdot 7 \mathrm{H}_{2} \mathrm{O}$ $(0.5 \%)$ and Thiourea $(10 \mathrm{mM})$ sprayed crop for maturity was 1570.3, 1566.5 for Water sprayed and 1541.4 over Control for rabi season 2013-14 and for rabi season 2014-15, AGDD requirement for $\mathrm{ZnSO}_{4} \cdot 7 \mathrm{H}_{2} \mathrm{O}(0.05 \%)$, Thiourea $(10 \mathrm{mM})$, Water sprayed over Control for maturity stage were 1726.4, 1684.8, 1695.1 and 1653.2 respectively as shown in Table 1.

\subsection{Heliothermal units (HTU)}

The accumulated heliothermal units required to attain different phenological stages under different temperature regime, nitrogen level and post anthesis strategy of wheat were presented in (Table 1). Among temperature regime, highest helio thermal unit $\left(10892.6^{\circ} \mathrm{C}\right.$ day hours) were required for maturity to November 15 sown crop followed by November $30\left(10486.7^{\circ} \mathrm{C}\right.$ day hours $)$ October $30\left(10310.8^{\circ} \mathrm{C}\right.$ day hours $)$ sown crop during the rabi season 2013-14. This might be due to duration of sunshine hours were more in November 15 sown crop as compared to and November 30 and October 30 sown crop. During rabi season 2014-15, the data shows that the highest helio thermal unit $\left(11488.8^{\circ} \mathrm{C}\right.$ day hours $)$ were required for maturity to November 30 sown crop followed by October $30\left(10630.4{ }^{\circ} \mathrm{C}\right.$ day hours $)$ and November $15\left(10581.7^{\circ} \mathrm{C}\right.$ day hours) sown crop during rabi season 2014-15 because duration of bright sunshine hours were less in November 15 sown crop.

Among nitrogen level, highest heliothermal unit $\left(10974.4{ }^{\circ} \mathrm{C}\right.$ day hours) were acquired in $150 \%$ RDF treatment followed by $125 \% \operatorname{RDF}\left(10498.8{ }^{\circ} \mathrm{C}\right.$ day hours) and RDF (10216.9 ${ }^{\circ} \mathrm{C}$ day hours) treatment during rabi season 2013-14. During rabi season 2014-15, 150\% RDF treatment acquired highest heliothermal unit $\left(11253.9^{\circ} \mathrm{C}\right.$ day hours) followed by $125 \%$ $\operatorname{RDF}\left(10952.4^{\circ} \mathrm{C}\right.$ day hours $)$ and $\operatorname{RDF}\left(10494.6^{\circ} \mathrm{C}\right.$ day hours $)$ treatment.

Among post-anthesis strategies, the highest heliothermal unit $\left(10698.6{ }^{\circ} \mathrm{C}\right.$ day hours) requirement for $\mathrm{ZnSO}_{4} \cdot 7 \mathrm{H}_{2} \mathrm{O}$ $(0.05 \%)$ followed by Thiourea $(10 \mathrm{mM})\left(10638.2{ }^{\circ} \mathrm{C}\right.$ day hours), Water (10591.1 ${ }^{\circ} \mathrm{C}$ day hours) over Control (10325.6 ${ }^{\circ} \mathrm{C}$ day hours) for rabi season 2013-14 and for rabi season 2014-15, heliothermal requirement for $\mathrm{ZnSO}_{4} .7 \mathrm{H}_{2} \mathrm{O}(0.5 \%)$, Thiourea $(10 \mathrm{mM})$, Water sprayed over Control for maturity were $11150.8,10886.1,11040.7$ and $10523.5^{\circ} \mathrm{C}$ day hours respectively as shown in Table 1.

\subsection{Photothermal units (PTU)}

The variation in accumulated PTU in different temperature regimes, nitrogen levels and post anthesis strategies had been presented in (Table 1). Among temperature regime, APTU requirement for October 30 sown crop for maturity was $17773.5^{\circ} \mathrm{C}$ day hours, for November 15 , it was $17518.2{ }^{\circ} \mathrm{C}$ day hours and $17257.8^{\circ} \mathrm{C}$ day hours for November 30 sown crop for rabi season 2013-14 and for rabi season 2014-15, APTU requirement for October 30, November 15 and November 30 sown crop for maturity were 19919.2, 18907.0 and 18426.0 ${ }^{\circ} \mathrm{C}$ day hours respectively as shown in Table 3 . The higher APTU value in early sown crop may be due to fact that crop took longer duration to reach phenological stages.

Among the nitrogen level, APTU requirement for RDF from maturity was $17071.4{ }^{\circ} \mathrm{C}$ day hours, for $125 \% \mathrm{RDF}$, it was $17444.3{ }^{\circ} \mathrm{C}$ day hours and $18033.8{ }^{\circ} \mathrm{C}$ day hours for $150 \%$ RDF for rabi season 2013-14 and for rabi season 2014-15, APTU requirement for RDF, $125 \% \mathrm{RDF}$ and $150 \% \mathrm{RDF}$ from sowing to maturity were $19659.5,19270.2$ and $18322.4^{\circ} \mathrm{C}$ day hours respectively as shown in Table 1.

To avoid the heat stress during grain filling by spraying the crop at anthesis and after that at regular intervals with water or any stress alleviating chemicals help the crop to combat with this stress period. Among post-anthesis strategies, the APTU requirement for $\mathrm{ZnSO}_{4} .7 \mathrm{H}_{2} \mathrm{O}(0.05 \%)\left(17618.3{ }^{\circ} \mathrm{C}\right.$ day hours) and Thiourea $(10 \mathrm{mM})\left(17618.4{ }^{\circ} \mathrm{C}\right.$ day hours $)$ sprayed crop were highest at maturity followed by Water sprayed $\left(17573.2{ }^{\circ} \mathrm{C}\right.$ day hours) over Control $\left(17256.2{ }^{\circ} \mathrm{C}\right.$ day hours) for rabi season 2013-14 and for rabi season 201415 , AGDD requirement for $\mathrm{ZnSO}_{4} \cdot 7 \mathrm{H}_{2} \mathrm{O}(0.05 \%)$, Water sprayed, Thiourea $(10 \mathrm{mM})$ over Control for maturity stage were $19276.4,19312.1,19158.1$ and $18589.6{ }^{\circ} \mathrm{C}$ day hours respectively as shown in Table 1.

\subsection{Heat use efficiency (HUE)}

Heat use efficiency was also computed for grain and biological 
yield of wheat and presented in Table 2. The heat use efficiency went on increasing from vegetative growth up to physiological maturity of the crop. Among the dates of sowing, heat use efficiency was found to be higher for earlier sown crop and it decreased with delay in sowing. The highest heat use efficiency (2.78 $\mathrm{kg} \mathrm{ha}^{-1}{ }^{\circ} \mathrm{C}$ day ${ }^{-1}$ for grain and $7.97 \mathrm{~kg} \mathrm{ha}^{-1}{ }^{\circ} \mathrm{C}_{\text {day }}{ }^{-1}$ for biological yield) was recorded under the October 30 sown crop followed by $\left(2.53 \mathrm{~kg} \mathrm{ha}^{\circ} \mathrm{C}_{\text {day }}{ }^{-1}\right.$ for grain and $7.21 \mathrm{~kg} \mathrm{ha}^{-1}{ }^{\circ} \mathrm{C}$ day $^{-1}$ for biological yield) November 15 and $\left(2.45 \mathrm{~kg} \mathrm{ha}^{-1}{ }^{\circ} \mathrm{C}\right.$ day $^{-1}$ for grain and $6.62 \mathrm{~kg} \mathrm{ha}^{-1}{ }^{\circ} \mathrm{C}_{\text {day }}{ }^{-1}$ for biological yield) for November 30 sown crop during rabi season 2013-14. During rabi season 2014-15, highest heat use efficiency $\left(3.67 \mathrm{~kg} \mathrm{ha}^{-1}\right.$ ${ }^{\circ} \mathrm{C}_{\text {day }}{ }^{-1}$ for grain and $8.70 \mathrm{~kg} \mathrm{ha}^{-1}{ }^{\circ} \mathrm{C}_{\text {day }}{ }^{-1}$ for biological yield) was recorded under the October 30 sown crop followed by November 15 (3.49 $\mathrm{kg} \mathrm{ha}^{-1}{ }^{\circ} \mathrm{C}$ day ${ }^{-1}$ for grain and $8.24 \mathrm{~kg} \mathrm{ha}^{-1}$ ${ }^{\circ} \mathrm{C}_{\text {day }}{ }^{-1}$ for biological yield $)$ and November $30\left(3.29 \mathrm{~kg} \mathrm{ha}^{-1}\right.$ ${ }^{\circ} \mathrm{C}$ day ${ }^{-1}$ for grain and $7.43 \mathrm{~kg} \mathrm{ha}^{-1}{ }^{\circ} \mathrm{C}_{\text {day }}{ }^{-1}$ for biological yield) sown crop. Subsequent delay in sowing resulted in decrease in the heat use efficiency. The timely sown wheat crop seems to be essential for harnessing the good impact of prevailing weather conditions. Kumari et al. (2009) also reported that timely sown wheat crop exhibited maximum heat use efficiency.

Among the nitrogen levels the highest heat use efficiency was

Table 2: Heat use efficiency $\left(\mathrm{kg} \mathrm{ha}^{-1}{ }^{\circ} \mathrm{C}\right.$ day $\left.{ }^{-1}\right)$ under different thermal regimes, nitrogen levels and post-anthesis strategy

\begin{tabular}{|c|c|c|c|c|}
\hline \multirow[t]{3}{*}{ Treatment } & \multicolumn{4}{|c|}{ Heat Use Efficiency $\left(\mathrm{kg} \mathrm{ha}^{-1}{ }^{\circ} \mathrm{C}_{\text {day }}{ }^{-1}\right)$} \\
\hline & \multicolumn{2}{|c|}{ Grain } & \multicolumn{2}{|c|}{ Biomass } \\
\hline & $2013-14$ & $2014-15$ & $2013-14$ & $2014-15$ \\
\hline \multicolumn{5}{|c|}{ Temperature regimes } \\
\hline October 30 & 2.92 & 3.45 & 7.98 & 8.97 \\
\hline November 15 & 2.79 & 3.31 & 7.72 & 8.71 \\
\hline November 30 & 2.62 & 3.01 & 7.37 & 8.05 \\
\hline $\mathrm{CD}(p=0.05)$ & 0.21 & 0.25 & 0.49 & 0.67 \\
\hline \multicolumn{5}{|l|}{ Nitrogen levels } \\
\hline RDF & 2.47 & 3.07 & 6.91 & 8.04 \\
\hline $125 \% \mathrm{RDF}$ & 2.86 & 3.28 & 7.99 & 8.63 \\
\hline $150 \% \mathrm{RDF}$ & 3.01 & 3.42 & 8.16 & 9.05 \\
\hline $\mathrm{CD}(p=0.05)$ & 0.19 & 0.20 & 0.60 & 0.44 \\
\hline \multicolumn{5}{|c|}{ Post anthesis strategies } \\
\hline Control & 2.45 & 3.08 & 7.22 & 8.37 \\
\hline Water sprayed & 2.64 & 3.26 & 7.59 & 8.59 \\
\hline $\begin{array}{l}\mathrm{ZnSO}_{4} \cdot 7 \mathrm{H}_{2} \mathrm{O} \\
(0.5 \%)\end{array}$ & 3.07 & 3.38 & 8.11 & 8.71 \\
\hline Thiourea (10 mM) & 2.96 & 3.32 & 7.85 & 8.64 \\
\hline $\mathrm{CD}(p=0.05)$ & 0.20 & 0.12 & 0.44 & 0.29 \\
\hline
\end{tabular}

found in $150 \%$ RDF treatment $\left(2.80 \mathrm{~kg} \mathrm{ha}^{-1}{ }^{\circ} \mathrm{C}\right.$ day ${ }^{-1}$ for grain and $8.05 \mathrm{~kg} \mathrm{ha}^{-1}{ }^{\circ} \mathrm{C}$ day ${ }^{-1}$ for biological yield) followed by $125 \%$ $\operatorname{RDF}\left(2.55 \mathrm{~kg} \mathrm{ha}^{-1}{ }^{\circ} \mathrm{C}\right.$ day $^{-1}$ for grain and $7.26 \mathrm{~kg} \mathrm{ha}^{-1}{ }^{\circ} \mathrm{C}$ day ${ }^{-1}$ for biological yield $)$ and $\mathrm{RDF}\left(2.46 \mathrm{~kg} \mathrm{ha}^{-1}{ }^{\circ} \mathrm{C}\right.$ day ${ }^{-1}$ for grain and $6.65 \mathrm{~kg} \mathrm{ha}^{-1}{ }^{\circ} \mathrm{C}$ day ${ }^{-1}$ for biological yield) during rabi season 2013-14. During rabi season 2014-15, among the nitrogen levels the highest heat use efficiency was found in $150 \% \mathrm{RDF}$ treatment $\left(3.72 \mathrm{~kg} \mathrm{ha}^{-1}{ }^{\circ} \mathrm{C}\right.$ day ${ }^{-1}$ for grain and $8.72 \mathrm{~kg} \mathrm{ha}^{-1}{ }^{\circ} \mathrm{C}$ day $^{-1}$ for biological yield) followed by $125 \%$ RDF $(3.52 \mathrm{~kg}$ $\mathrm{ha}^{-1}{ }^{\circ} \mathrm{C}$ day ${ }^{-1}$ for grain and $7.28 \mathrm{~kg} \mathrm{ha}^{-1}{ }^{\circ} \mathrm{C}_{\text {day }}{ }^{-1}$ for biological yield) and RDF (3.30 kg ha-1 ${ }^{\circ} \mathrm{C} \mathrm{day}^{-1}$ for grain and $7.48 \mathrm{~kg}$ $\mathrm{ha}^{-1}{ }^{\circ} \mathrm{C}$ day ${ }^{-1}$ for biological yield). The increase in nitrogen application significantly increases the heat use efficiency of wheat crop. Mandic et al. (2015); Pradhan et al. (2014) also reported that higher nitrogen application significantly resulted in higher radiation use efficiency.

Among the post-anthesis strategies, highest heat use efficiency was obtained under $\mathrm{ZnSO}_{4} .7 \mathrm{H}_{2} \mathrm{O}(0.5 \%)\left(2.77 \mathrm{~kg} \mathrm{ha}^{-1}{ }^{\circ} \mathrm{C}_{\text {day }}{ }^{-1}\right.$ for grain and $7.89 \mathrm{~kg} \mathrm{ha}^{-1}{ }^{\circ} \mathrm{C}$ day $^{-1}$ for biological yield) followed by Thiourea $(10 \mathrm{mM})\left(2.62 \mathrm{~kg} \mathrm{ha}^{-1}{ }^{\circ} \mathrm{C}\right.$ day $^{-1}$ for grain and 7.61 $\mathrm{kg} \mathrm{ha}^{-1}{ }^{\circ} \mathrm{C}$ day ${ }^{-1}$ for biological yield), Water $\left(2.53 \mathrm{~kg} \mathrm{ha}^{-1}{ }^{\circ} \mathrm{C}\right.$ day $^{-1}$ for grain and $7.27 \mathrm{~kg} \mathrm{ha}^{-1}{ }^{\circ} \mathrm{C}$ day $^{-1}$ for biological yield) over Control $\left(2.43 \mathrm{~kg} \mathrm{ha}^{-1}{ }^{\circ} \mathrm{C}_{\text {day }}{ }^{-1}\right.$ for grain and $6.50 \mathrm{~kg} \mathrm{ha}^{-1}{ }^{\circ} \mathrm{C}$ day $^{-1}$ for biological yield) during rabi season 2013-14. During rabi season 2014-15, highest heat use efficiency was obtained under $\mathrm{ZnSO}_{4} \cdot 7 \mathrm{H}_{2} \mathrm{O}(0.5 \%)\left(3.65 \mathrm{~kg} \mathrm{ha}^{-1}{ }^{\circ} \mathrm{C}_{\text {day }}{ }^{-1}\right.$ for grain and $8.67 \mathrm{~kg} \mathrm{ha}^{-1}{ }^{\circ} \mathrm{C}$ day ${ }^{-1}$ for biological yield) followed by Thiourea $(10 \mathrm{mM})\left(3.54 \mathrm{~kg} \mathrm{ha}^{-1}{ }^{\circ} \mathrm{C}\right.$ day ${ }^{-1}$ for grain and $8.37 \mathrm{~kg} \mathrm{ha}^{-1}{ }^{\circ} \mathrm{C}$ day $^{-1}$ for biological yield), Water $\left(3.40 \mathrm{~kg} \mathrm{ha}^{-1}{ }^{\circ} \mathrm{C}_{\text {day }}{ }^{-1}\right.$ for grain and $8.13 \mathrm{~kg} \mathrm{ha}^{-1}{ }^{\circ} \mathrm{C}_{\text {day }}{ }^{-1}$ for biological yield) over Control (3.29 $\mathrm{kg} \mathrm{ha}^{-1}{ }^{\circ} \mathrm{C}_{\text {day }}{ }^{-1}$ for grain and $7.32 \mathrm{~kg} \mathrm{ha}^{-1}{ }^{\circ} \mathrm{C} \mathrm{day}^{-1}$ for biological yield). The foliar spray with $\mathrm{ZnSO}_{4} @ 0.5 \%$ at anthesis and 20 days interval after anthesis significantly increases the heat use efficiency of wheat crop over other treatments.

\subsection{Grain yield $\left(q h a^{-1}\right)$}

The grain yield was significantly affected by the temperature regime, nitrogen level and non significant differences was observed at post-anthesis strategies (Table 1). The maximum grain yield $\left(46.29 \mathrm{q} \mathrm{ha}^{-1}\right)$ was recorded under October 30 sown crop followed by (42.73 q ha ${ }^{-1}$ ) November 15 and (38.57 q $\mathrm{ha}^{-1}$ ) for November 30 sown crop during rabi season 201314. During rabi season 2014-15, maximum grain yield (49.45 $\mathrm{q} \mathrm{ha}^{-1}$ ) was recorded at harvesting under October 30 sown crop followed by November 15 (44.88 q ha-1) and November 30 (41.72 $\mathrm{q} \mathrm{ha}^{-1}$ ) sown crop. The crop sown during November 15 produced straw yield statistically at with the October 30 during 2013-14 and with November 30 sown crop during both the years. 
Among the nitrogen level, maximum grain yield (47.36 $\left.\mathrm{q} \mathrm{ha}^{-1}\right)$ was produced at harvesting in $150 \%$ RDF followed by $125 \%$ RDF (43.21 $\left.\mathrm{q} \mathrm{ha}^{-1}\right)$ and RDF (39.03 $\left.\mathrm{q} \mathrm{ha}^{-1}\right)$ during rabi season 2013-14. The crop sown during November 15 produced straw yield statistically at with the November 30 during 2014-15.

Among the post-anthesis strategies, although no significant difference in straw yield was recorded but crop without any spray had higher straw yield (75.49 $\left.\mathrm{q} \mathrm{ha}^{-1}\right)$ followed by $\mathrm{ZnSO}_{4} .7 \mathrm{H}_{2} \mathrm{O}(0.05 \%)$ (75.37 q ha $\left.{ }^{-1}\right)$, Water sprayed (75.29 $\left.\mathrm{q} \mathrm{ha}^{-1}\right)$ over Thiourea $(10 \mathrm{mM})$ during rabi season 2013-14. During rabi season 2014-15, no significant difference in straw yield were recorded under different spray treatments but crop sprayed with $\mathrm{ZnSO}_{4} \cdot 7 \mathrm{H}_{2} \mathrm{O}(0.5 \%)$ had slightly higher straw yield (79.25 $\left.\mathrm{q} \mathrm{ha}^{-1}\right)$ followed by Water sprayed (79.19 $\left.\mathrm{q} \mathrm{ha}^{-1}\right)$, Thiourea (10 mM) (78.37 q ha-1) over Control (78.32 $\left.\mathrm{q} \mathrm{ha}^{-1}\right)$.

\section{Relationship of Grain Yield with Agroclimatic Indices}

Wheat crop is exposed to a variety of weather conditions during its different phenophases of growth, resulting in large variations in growth rate and yield. Air temperature based agromet indices viz., growing degree days (GDD), heat use efficiency (HUE) have been used to describe changes in phenological behaviour and growth parameters. The growing degree days concept provides a reliable index for the progress of the crop that can be used to predict the yield of any crop.

\subsection{Grain yield and $A G D D$}

The relation between grain yield and accumulated growing degree days were calculated for rabi seasons 2013-14 and 2014-15 as shown in Figure 2a and 2b respectively. There was positive and linear relationship exists between the grain yield and accumulated growing degree days during crop growing season of 2013-14, which explained $64.8 \%$ variability and during crop growing season of 2014-15, their relationship showed $71.1 \%$ variability. As more the number of days taken by the crop to complete its phenological stages had a positive effect on the grain yield.

\subsection{Grain yield and $H U E$}

The heat use efficiency went on increasing from vegetative growth up to physiological maturity of the crop. The heat use efficiency was found to be higher for earlier sown crop and it decreased with delay in sowing. The relation between grain yield and heat use efficiency for grains was calculated for crop growing seasons of 2013-14 and 2014-15 as shown in Figure $3 \mathrm{a}$ and $3 \mathrm{~b}$ respectively. It showed linear and positive relationship between grain yield and heat use efficiency with $73.8 \%$ variability during rabi season $2013-14$ and $77.6 \%$ variability during crop growing season of 2014-15.
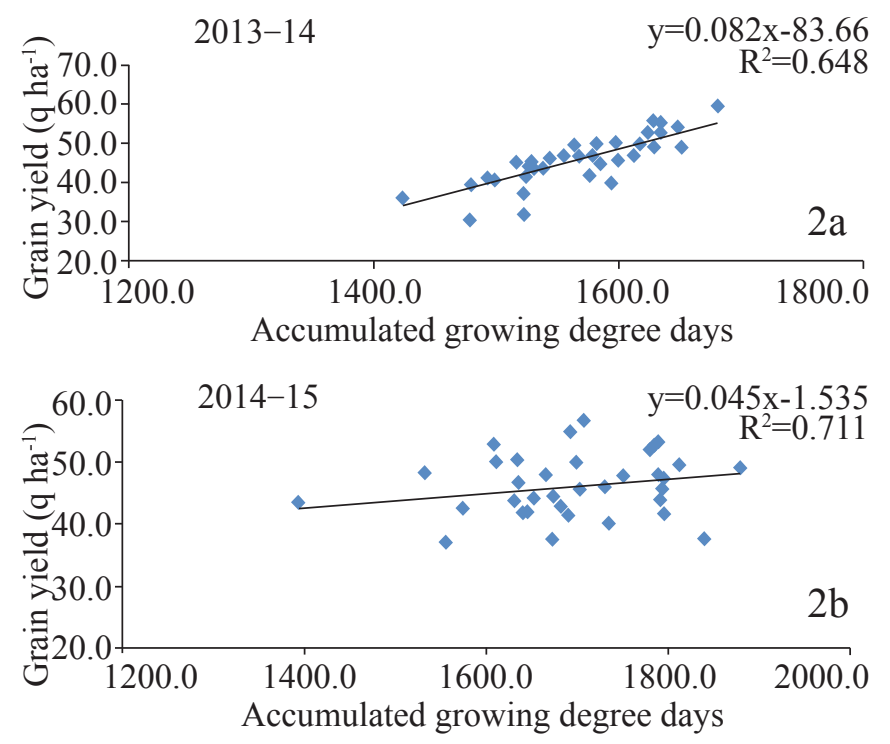

Figure $2 \mathrm{a}$ and $2 \mathrm{~b}$ : Relationship between grain yield and accumulated growing degree days during crop growing seasons of 2013-14 and 2014-15
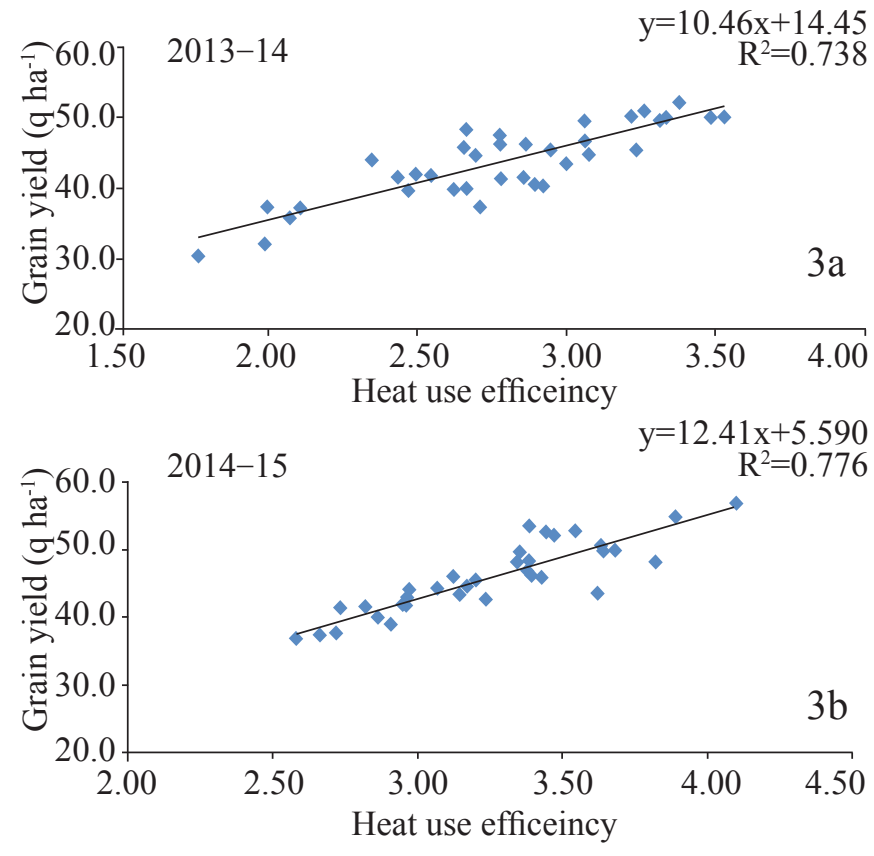

Figure $3 \mathrm{a}$ and $3 \mathrm{~b}$ : Relationship between grain yield and heat use efficiency during crop growing seasons of 2013-14 and 2014-15

\section{Conclusion}

The crop sown on October 30 took maximum calendar days, GDD, PTU for maturity which was significantly reduced with delay in sowing time and recorded lowest value on the November 30 sown crop. The timely sown wheat crop performed better in terms of accumulation and utilization of heat units. Because of very close relation between temperature and plant development, it is very important to derive exact 
information on the duration of phenological stages and their effect on grain yield.

\section{Acknowledgement}

The authors are highly thankful to Department of Science and Technology (DST), Govt of India, New Delhi for providing grant for conducting the experiments in the form of INSPIRE fellowship.

\section{References}

Amrawat, T., Solanki, N.S., Sharma, S.K., Jajoria, D.J., Dotaniya, M.L., 2013. Phenology growth and yield of wheat in relation to agrometeorological indices under different sowing dates. African Journal of Agricultural Research 8, 6366-6374.

Bishnoi, O.P., Singh, S., Niwas, R., 1995. Effect of temperature on phenological development of wheat (Triticum aestivum L.) crop in different row orientations. Indian Journal of Agricultural Sciences 65, 211-214.

Kaur, A., Pannu, R.K., 2008. Effect of sowing time and nitrogen schedules on phenology, yield and thermal-use efficiency of wheat (Triticum aestivum). Indian Journal of Agricultural Sciences 78, 366-369.

Khichar, M.L., Niwas, R., 2007. Thermal effect on growth and yield of wheat under different sowing environments and planting systems. Indian Journal of Agriculture Research 41, 92-96.

Kumari, P., Wadood, A., Singh, R.S., Kumar, R., 2009. Response of wheat crop to different hydrothermal regimes under the agroclimatic conditions of Jharkhand. Journal of Agrometeorology 11, 85-88.

Mandic, V., Krnjajai, V., Tomic, Z., Bijelici, Z., Simic, A., Muslic, D.R., Gogic, M., 2015. Nitrogen fertilizer influence on wheat yield and use efficiency under different environmental conditions. Chilean Journal of Agricultural Research 75, 92-97.
Nuttonson, M.Y., 1955. Wheat climatic relationship and use of phenology in ascertaining the thermal and photothermal requirements of wheat. American Institute of Crop Ecology, Washington D.C.

Pandey, I.B., Pandey, R.K., Dwivedi, D.K., Singh, R.S., 2010. Phenology, heat unit requirement and yield of wheat varieties under different crop growing environment. Indian Journal of Agricultural Sciences 80, 136-140.

Paul, N.K., Sarker, D.K., 2000. Accumulated heat units and phenology relationships in wheat as influenced by sowing dates. Bangladesh Journal of Botany 29, 49-54.

Pradhan, S., Sehgal, V.K., Sahoo, R.N., Bandyopadhyay, K.K., Singh, R., 2014. Yield, water, radiation and nitrogen use efficiencies of wheat (Triticum aestivum) as influenced by nitrogen levels in a semi-arid environment. Indian Journal of Agronomy 59, 267-275.

Sandhu, I. S., Sharma, A.R., Sur, H.S., 1999. Yield performance and heat unit requirement of wheat varieties as affected by sowing dates under rainfed conditions. Indian Journal of Agricultural Sciences 69, 175-179.

Sikder, S., 2008. Accumulated heat unit and phenology of wheat cultivars as influenced by late sowing heat stress condition. Agricultural Rural Development 7, 57-64.

Sourour, A., Afef, O., Nadia, C.H., Mounir, R., Mongi, B.Y., 2016. Relation between agro- meteorological indices, heading date and biological/grain yield of durum wheat genotypes. Journal of Research of Agriculture and Animal Sciences 3, 01-06.

Suleiman, A.A., Nganya, J.F., Ashraf, M.A., 2014. Effect of cultivar and sowing date on growth and yield of Wheat (Triticum aestivum L.) in Khartoum, Sudan. Journal of Forest Products and Industries 3, 198-203.

Tacka, J., Barkleyb, A., Lawton, L.N., 2015. Effect of warming temperatures on US wheat yields. Proceedings National Academy of Sciences 112, 6931-6936. 